\title{
Air Pollution Injuries to Vegetation in Taiwan
}

Taiwan is an island $395 \mathrm{~km}$ long and $144 \mathrm{~km}$ wide, located between 21 and $25^{\circ}$ north latitude and 119 and $124^{\circ}$ east longitude, with a population of 20 million, making it one of the most crowded countries in the world. Chinese settlement of the island began in the 12th century, and large numbers of Chinese, mostly from the east coast of China, came in the 17 th century. Modernization began after the government of the Republic of China moved to the island in 1949. During the past four decades, individuals and the government have engaged in substantial industrial investment, first in labor-intensive manufacturing industries, then gradually shifting to heavy or high-technology industries. The export-oriented economy of Taiwan was not accomplished by a few big companies but rather resulted from the collective contributions of tens of thousands of small factories. From 1952 to 1990 , the real gross national product grew at an average annual rate of nearly $9 \%$ (1). The annual per capita income was $\$ 7,500$ (U.S.) in 1989 and over $\$ 10,000$ in 1992. In 1992, Taiwan boasted the world's largest foreign exchange reserves: $\$ 80$ billion (U.S.).

Taiwan is now classified as a newly industrialized country and is referred to as one of Asia's "Four Little Dragons" by economists. As in any industrialized country, however, economic success has a number of drawbacks, including air pollution that injures plant life.

\section{Distribution of Agriculture and Natural Resources}

The fundamental topographic feature of Taiwan is the central range of high

Dr. Sun's add ress is: Department of Plant Pathology and Entomology, National Taiwan University, Taipei, Taiwan.

1994 The American Phytopathological Society mountains running from the northeast corner to the southern tip of the island. About three-fifths of the island is covered by hills and mountains. Most of the population and human activities, including agriculture and industry, are located on the western side, which includes a few basins and a southwestern plain.

Taiwan has more than 200 mountains with an elevation of over $3,000 \mathrm{~m}$. Because of the island's subtropical climate and complicated topography, vegetation types are diverse and abundant. The high altitude of the mountains provides climatic and vegetation zones ranging from tropical to alpine. Agriculture is concentrated in the fertile alluvial plains or basins. Taiwan has 15 families, 55 genera, and 537 species of ferns and 175 families, 1,079 genera, and 3,305 species of seed plants. Endemic species are relatively numerous, amounting to about $40 \%$ of the total (1). The Council of Agriculture and many private groups in the Republic of China are working to protect wildlife, including rare plant species. Wildlife conservation efforts are carried out under a legal framework composed of the $\mathrm{Na}$ tional Park Law, the Cultural Assets Preservation Law, and the Wildlife Conservation Law (1).

Taiwan was once entirely covered by forests, but forested areas today are estimated at only 1.9 million ha, including all the high mountains and most of the hills. A 5-year reforestation program accompanied by soil conservation projects has been implemented to preserve the health of woodlands and protect the environment on the island. Recently, the government has been encouraging farmers to reforest agricultural areas to conserve soil and to serve as windbreaks and as classrooms for environmental education.

Over 900,000 ha of land were cultivated on Taiwan in 1992: 454,000 ha for rice paddies and alternate crops, 222,000 ha for fruit, and 230,000 ha for vegetables (1). Among the major crops are rice (Oryza sativa L.), corn (Zea mays L.), soybean (Glycine max (L.) Merr.), sugarcane (Saccharum officinarum L.), and tea (Camellia sinensis (L.) Kuntze).

\section{Air Pollutants: Sources, Types, and Distribution}

The number of factories on the island increased from about 48,700 in 1982 , to 81,700 in 1988 , to 94,670 in 1992 . Most are located on the crowded west coast, where there are, on the average, approximately six factories per square kilometer.

Kaohsiung harbor in the south and Keelung harbor in the north are the most important doors for foreign trade, and the heavy industries, such as steel and petrochemical plants, oil refineries, and shipyards, are distributed mostly in these two areas. A comprehensive survey during the past 10 years of foliar injury to vegetation induced by air pollution showed that most episodes occurred in the western counties of Kaohsiung and Taipei (Fig. 1). However, the light in-

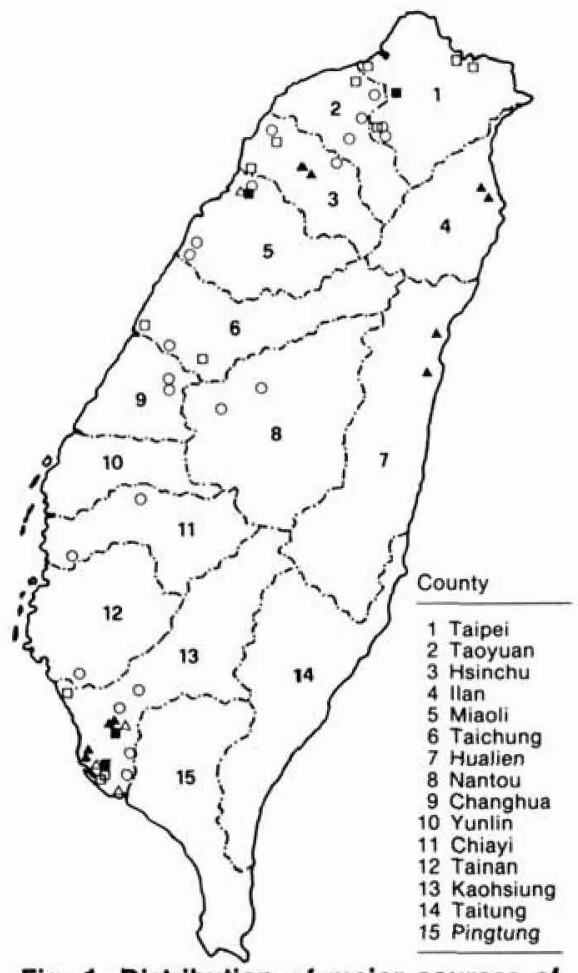

Fig. 1. Distribution of major sources of air pollution causing injuries to vegetation in Taiwan, including the sources of fluoride $(O)$, sulfur dioxide $(\square)$, chlorine $(\square)$, hydrogen chloride $(\Delta)$, and cement dust $(\boldsymbol{\Delta})$. 
dustries, including cement, textile, brick, ceramic, food, fertilizer, chemical, machinery, and metal factories, are located more evenly on the plains throughout the island. Both particulate matter and gaseous (primary and secondary) pollutants are emitted from these sources (Table 1).

The air pollution problem is further aggravated by engine exhaust from automobiles and motorcycles. The number of automobiles on the island increased from 1.4 million in 1986 to 3.3 million in 1992, and the number of motorcycles rose from 5.2 million to 10.6 million. The yearly rate of increase in motor vehicles is $18 \%$, and the emissions from these vehicles serve as precursors for secondary pollutants such as ozone, peroxyacetyl nitrate, and nitric acid.

The Taiwan Environmental Protection Administration (EPA) operates 19 air-quality monitoring stations on the island, using methods designated by the U.S. EPA or equivalent techniques $(3,4)$ to measure air pollutants such as sulfur dioxide, nitrogen oxides, carbon monoxide, ozone, hydrocarbons, and total suspended particulate matter. The data gathered are expressed in a pollutant standard index (PSI) ranging from 0 to $500(8)$, in which $0-50=$ good, $51-100$ $=$ moderate, $101-100=$ unhealthy, 200-299 = very unhealthy, and 300-500 $=$ hazardous. In $1990,1,090$ of the 6,673 station days (or $16.3 \%$ ) monitored for pollution registered a PSI exceeding 100, compared with 979 station days (or $15.1 \%$ ) in 1989 , indicating a deterioration in air quality.

In recent years, peroxyacetyl nitrate has been found to exceed phytotoxic levels in all three major urban areas: Taipei in the north, Taichung in the center, and Kaohsiung in the south $(6,14)$. Ambient concentrations, monitored by a gas chromatograph with an electron capture detector accompanied by a nitrogen oxide analyzer for calibration, fluctuated tremendously according to weather conditions $(6,14)$. On calm sunny days, concentrations frequently reached above $3.5-6.0 \mathrm{ppb}$ and caused foliar injury to some sensitive crops. From February 1992 to April 1993, there were 50 days with concentrations above the phytotoxic level in the Taipei area (6). The situations in Taichung and Kaohsiung were more serious because the weather conditions were more suitable to photochemical reactions.

Data from the 19 EPA monitoring stations showed that during 1984-1992, mean hourly ozone concentrations occasionally exceeded the set standard of 120 ppb. In 1986, for example, ozone hourly means were higher than $120 \mathrm{ppb}$ in three of 356 measuring days in Taichung County (3), in 14 of 206 measuring days in Taipei County (4), and in eight of 328 measuring days in Kaohsiung County (4). At monitoring stations in the north, the average number of hours with ozone hourly means higher than $120 \mathrm{ppb}$ was 12.6 in 1989 and 5.0 in 1992.

Ambient concentrations of fluoride at some locations with ceramic factories have ranged from 0 to $15 \mathrm{ppb}$, with a maximum daily mean of $9.7 \mathrm{ppb}$ and a monthly mean of $4.5 \mathrm{ppb}$ (16).

At most of the 19 EPA monitoring stations in 1992, the 24-hr mean concentrations of sulfur dioxide ranged from 0.027 to $0.180 \mathrm{ppm}$ and the yearly mean ranged from 0.015 to $0.044 \mathrm{ppm}$. At one monitoring station in an industrial area, the maximum 24-hr mean concentration was higher than $0.28 \mathrm{ppm}$ and the yearly mean was $0.083 \mathrm{ppm}$. Sulfur dioxide, however, is not a serious problem because the Taiwan EPA has enforced the use of low-sulfur fuel during the past 10 years (4).
In 1992, the maximum 24-hr mean concentration of ambient nitrogen dioxide at most of the 19 monitoring stations ranged from 0.013 to $0.217 \mathrm{ppm}$, with the yearly means ranging from 0.005 to $0.044 \mathrm{ppm}$. Therefore, the ambient levels of nitrogen dioxide are not considered to be harmful to vegetation at the present time (4).

\section{Impact of Pollutants on Plants}

History of air pollution injury to vegetation in Taiwan. During the 1960s, a mysterious disease of banana (Musa sapientum $\mathrm{L}$.) called marginal scorch was noticed in several orchards in southern Taiwan (11). Water-soaked, irregular lesions started from the margins of affected leaves and, as the disease progressed, coalesced and turned dark green or dark brown, with waves of new lesions appearing behind the old ones (Fig. 2). Fruit produced by affected plants were greatly reduced in size and not suitable for export. Because of the seriousness of the problem, the government allocated funds for plant pathologists in Taiwan to study this disease and also sought advice from foreign experts.

The problem remained unidentified until the mid-1970s, when W. H. Ko of the University of Hawaii was invited to inspect the diseased orchards and develop methods to tackle the problem. Experimental designs suggested by $\mathrm{Ko}$ revealed the disease to be noninfectious. When diseased plants from the affected area were planted among healthy plants in a nonaffected area, the disease did not spread to healthy plants and, furthermore, diseased plants became healthy. In addition, the disease originated from the air and not from the soil. Healthy plants planted in soil transported from the affected area to a nonaffected area did not become diseased, but healthy plants

Table 1. Major sources of air pollutants that injure vegetation in Taiwan

\begin{tabular}{|c|c|c|c|c|}
\hline Pollutants & Sources & Emissions & General process & Counties" \\
\hline \multicolumn{5}{|l|}{ Primary } \\
\hline \multirow[t]{3}{*}{ Hydrogen fluoride } & Brick factory & Continuous & $\mathrm{F}$ in clay $\rightarrow \mathrm{HF}$ & $\begin{array}{l}\text { Hsinchu, Miaoli, Changhua, } \\
\text { Kaohsiung }\end{array}$ \\
\hline & Ceramic factory & Continuous & $\mathrm{F}$ in raw material $\rightarrow \mathrm{HF}$ & Taipei, Hsinchu, Miaoli \\
\hline & Phosphate fertilizer factory & Continuous & Fluorapatite $+\mathrm{H}_{2} \mathrm{SO}_{4} \rightarrow \mathrm{HF}$ & Hsinchu, Miaoli, Kaohsiung \\
\hline \multirow[t]{6}{*}{ Sulfur dioxide } & Oil refinery & Accidental & $\mathrm{H}_{2} \mathrm{~S}+\mathrm{O}_{2} \rightarrow \mathrm{SO}_{2}$ & Taoyuan, Kaohsiung \\
\hline & Sulfuric acid factory & Accidental & $\mathrm{S}+\mathrm{O}_{2} \rightarrow \mathrm{SO}_{2}$ & Taoyuan, Miaoli, Kaohsiung \\
\hline & Oil-fired boiler & Continuous & $\mathrm{S}$ in fuel oil $+\mathrm{O}_{2} \rightarrow \mathrm{SO}_{2}$ & Taoyuan, Hsinchu, Kaohsiung \\
\hline & Oil-fired power plant & Continuous & $\mathrm{S}$ in fuel oil $+\mathrm{O}_{2} \rightarrow \mathrm{SO}_{2}$ & Taipei \\
\hline & Coal-fired power plant & Continuous & $\mathrm{S}$ in coal $+\mathrm{O}_{2} \rightarrow \mathrm{SO}_{2}$ & Taipei \\
\hline & Copper smelter & Continuous & $\mathrm{Cu}_{5} \mathrm{FeS}_{4}+\mathrm{O}_{2} \rightarrow \mathrm{SO}_{2}$ & Taipei \\
\hline \multirow[t]{2}{*}{ Chlorine } & Vinyl chloride monomer factory & Accidental & $\mathrm{Cl}_{2}$ leak & Miaoli, Kaohsiung \\
\hline & & Accidental & $\mathrm{Cl}_{2}$ leak & Miaoli, Kaohsiung \\
\hline \multirow{3}{*}{$\begin{array}{l}\text { Hydrogen chloride } \\
\text { Ammonia }\end{array}$} & Vinyl chloride monomer factory & Accidental & $\mathrm{C}_{2} \mathrm{H}_{4}+\mathrm{Cl}_{2} \rightarrow \mathrm{HCl}+\mathrm{VCM}$ & Miaoli, Kaohsiung \\
\hline & Refrigeration factory & Accidental & $\mathrm{NH}_{3}$ leak & Taoyuan, Kaohsiung \\
\hline & Fertilizer factory & Accidenta & $\mathrm{NH}_{3} \mathrm{l}$ & Hsinchu, Miaoli, Kaohsiung \\
\hline \multirow{2}{*}{\multicolumn{5}{|c|}{ Secondary }} \\
\hline Ozone & Automobi & & & \\
\hline Peroxyacetyl nitrate & Automobiles and motorcycles & Episodic & $\mathrm{HC}+\mathrm{NO}_{\mathrm{x}} \rightarrow \mathrm{PAN}$ & Taipei, Taichung, Kaohsiung \\
\hline
\end{tabular}

${ }^{a}$ See Figure 1. 


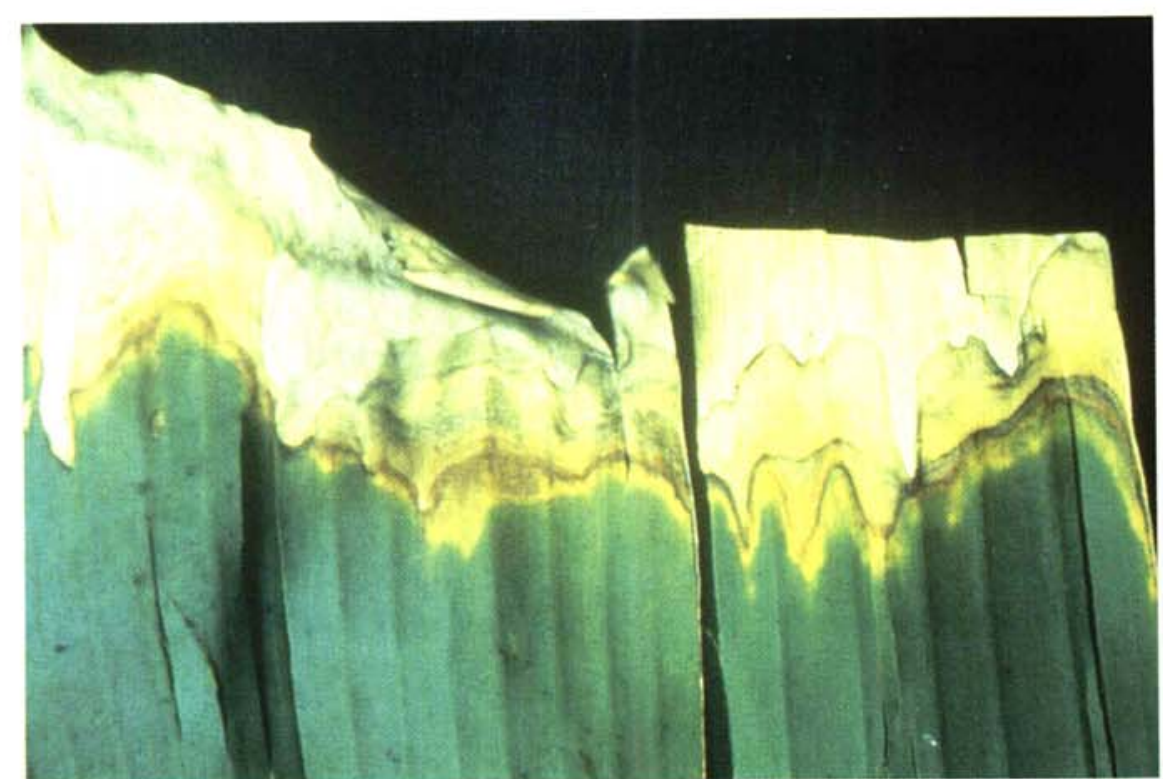

Fig. 2. Banana leaves showing symptoms of marginal scorch caused by hydrogen fluoride injury, with waves of new lesions forming behind old ones.

Table 2. Fluoride concentrations in plant tissues collected from polluted and nonpolluted areas in Taiwan

\begin{tabular}{|c|c|c|c|}
\hline \multirow[b]{2}{*}{ Plant tissue sample } & \multicolumn{3}{|c|}{ Fluoride concentration $(\mu \mathrm{g} / \mathrm{g})$} \\
\hline & $\begin{array}{l}\text { Necrotic } \\
\text { portion" }\end{array}$ & $\begin{array}{c}\text { Nonnecrotic } \\
\text { portion }\end{array}$ & Control $^{\mathrm{b}}$ \\
\hline \multicolumn{4}{|l|}{ Rice (Oryza sativa) } \\
\hline Slightly injured leaf & 460 & 120 & 10 \\
\hline Severely injured leaf & 1,280 & 220 & 10 \\
\hline Injured ratoon leaf & 3,950 & 920 & 15 \\
\hline Injured immature grain & $\ldots$ & 110 & 6 \\
\hline Injured full grain & $\ldots$ & 20 & 3 \\
\hline Banana (Musa sapientum) leaf & 750 & 90 & 4 \\
\hline Sweetpotato (Ipomoea batatas) leaf & 570 & 230 & 9 \\
\hline Bo-tree fig (Ficus religiosa) leaf & 1,180 & 440 & 7 \\
\hline Beakpot eucalyptus ( $E$. robusta) leaf & 1,030 & 580 & 7 \\
\hline Hedge bamboo (Bambusa multiplex) leaf & 1,100 & 580 & 10 \\
\hline Acacia tree $(A$. confusa $)$ petiole & 670 & 170 & 6 \\
\hline Guava (Psidium guajava) leaf & 450 & 190 & 10 \\
\hline Chinese hibiscus (H. rosa-sinensis) leaf & $\ldots$ & 1,030 & 7 \\
\hline
\end{tabular}

${ }^{a}$ Usually the leaf margin or tip.

${ }^{b}$ Corresponding part from healthy plant.

in soil from a nonaffected area and transported to the affected area all developed marginal scorch. The causal agent finally was found to be hydrogen fluoride emitted from nearby brick factories (11). Analysis of leaf tissues showed that the concentration of fluoride was about 10 times higher in diseased leaves than in healthy leaves (11). Healthy leaves fumigated with hydrogen fluoride vapor developed symptoms of marginal scorch indistinguishable from those occurring in nature, and fluoride content increased more than sixfold in diseased tissues (11). This was the first record of a plant disease caused by an air pollutant in Taiwan. Since then, foliar injury induced by various air pollutants has been reported on a number of agricultural crops and forest tree species. As a result, a diagnostic pictorial atlas of air pollution injury on
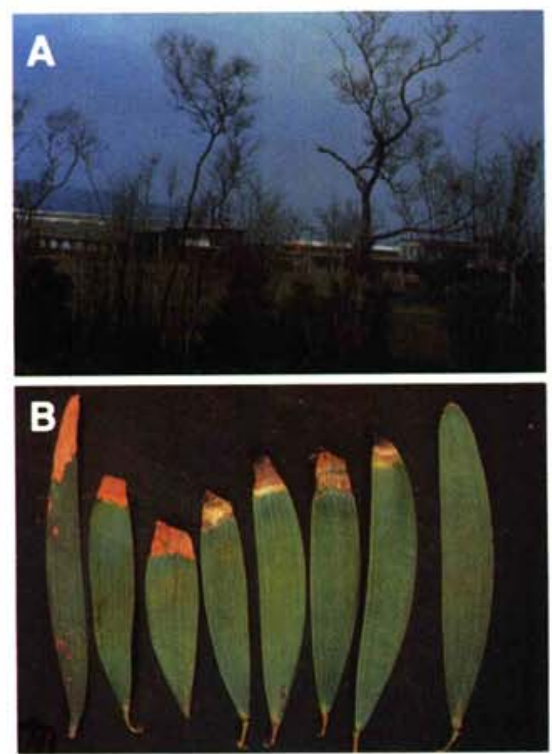

Fig. 3. Hydrogen fluoride emitted from ceramic factories at Ying Ko, Taipei, (A) killed acacia trees used as windbreaks, with (B) tip necrosis of petioles the main sign of injury.

about $20 \mathrm{~km}$ south of Taipei, has nearly 600 ceramic factories for production of porcelain or tile, most of which are small and family-owned.

Fluoride was found to affect many ornamental and crop plants in addition to banana in several industrial areas. Hydrogen fluoride killed acacia trees (Acacia confusa Merr.) used as windbreaks near Ying Ko ceramic factories (Fig. 3A); the main symptom was tip necrosis on petioles (Fig. 3B). The pollutant also caused severe chlorosis and tip necrosis on leaves and glumes of rice in about 300 ha of paddy fields in that area (16). Other effects of the pollutant included tip necrosis of gladiolus (Gladiolus gandavensis Van Houtte) and hedge bamboo (Bambusa multiplex (Lour.) Raeusch) and marginal scorch of white mulberry (Morus alba L.), bo-tree fig (Ficus religiosa L.), beakpot eucalyptus (Eucalyptus robusta $\mathrm{Sm}$.), peanut (Arachis hypogaea L.), sweetpotato (Ipomoea batatas (L.) Lam.), pear (Pyrus lindleyi Rehd.), mango (Mangifera indica L.), longan (Euphoria longana Lam.), and guava (Psidium guajava L.) (12). The symptoms were similar to those reported by others (20). Fluoride concentrations in injured tissues were increased from several dozen to over 100 times normal (Table 2) and were consistent with those described in the literature (2).

Ozone. During the early 1970s, ozone caused slight leaf weather fleck symptoms on the tobacco (Nicotiana tabacum L.) cultivar Bel-W3 in the central county of Taichung $(10,17)$. Because VamHicks, which was tolerant to ozone injury, was the predominant tobacco cultivar grown in Taiwan, the disease did not affect yield significantly and was largely ignored for about 20 years. 


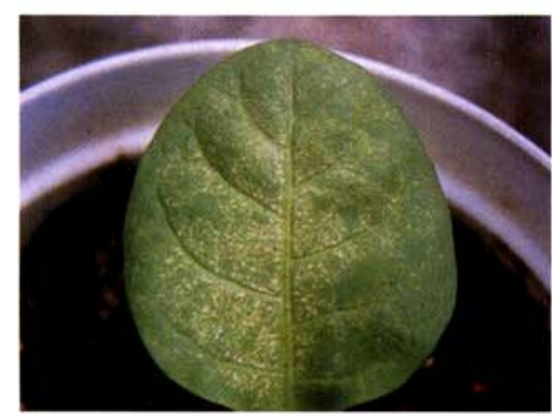

Fig. 4. Weather fleck symptoms on tobacco leaf caused by ozone in ambient concentrations of over $120 \mathrm{ppb}$.

In the autumn of 1992, Bel-W3 plants grown in the greenhouse of National Taiwan University showed weather fleck symptoms (Fig. 4) similar to those described in the literature (7). These symptoms appeared three times during that season. In addition, a few other sensitive plants such as spinach (Spinacia oleracea L.) and leafy sweetpotato in a nearby field also showed ozone-type symptoms concurrently (15). Exposure of these plants to $80-200 \mathrm{ppb}$ of ozone in continuous stirred tank reactors reproduced the symptoms observed in nature. The ambient ozone concentrations monitored at the campus were $120 \mathrm{ppb}$ at noon during that period. These results suggest that ozone has been a problem for vegetation since 1970, although causing less foliar injury than peroxyacetyl nitrate.

Peroxyacetyl nitrate. Injury caused by peroxyacetyl nitrate (PAN) was first noticed in 1989 in Taipei County on the local lettuce (Lactuca sativa L.) cultivars Sword-leaf and Round-leaf (14). Both cultivars showed the characteristic symptoms of bronzing and silvering on the abaxial leaf surface (Fig. 5A and B), especially of new, fully developed leaves. A subsequent survey showed that PAN also injured these crops in Taichung and Kaohsiung counties. Estimates of the total area affected ranged from 6,000 to $10,000 \mathrm{ha}$, and some fields sustained yield losses of approximately $60 \%$ (14).

PAN also caused silvering and/or bronzing symptoms on the lower leaf surface of spinach (Fig. 5C), petunia (Petunia $\times$ hybrida Hort. Vilm.-Andr.), Swiss chard (Beta vulgaris L. subsp. cicla (L.) W. Koch), black nightshade (Solanum nigrum L.), quickweed (Galinsoga parviflora Cav.), Nicotiana excelsior J.M. Black (Fig. 5D), and sweet basil (Ocimum basilicum L.) (6). The symptoms were similar to those described in the literature $(18,19)$. Exposure of these plants to $15-20 \mathrm{ppb}$ of PAN in continuous stirred tank reactors for 3-6 hours reproduced the symptoms observed in nature $(6,14)$.

\section{Use of Indicator Plants}

Although PAN and ozone may simultaneously affect sensitive plants such as spinach, tobacco, and black nightshade
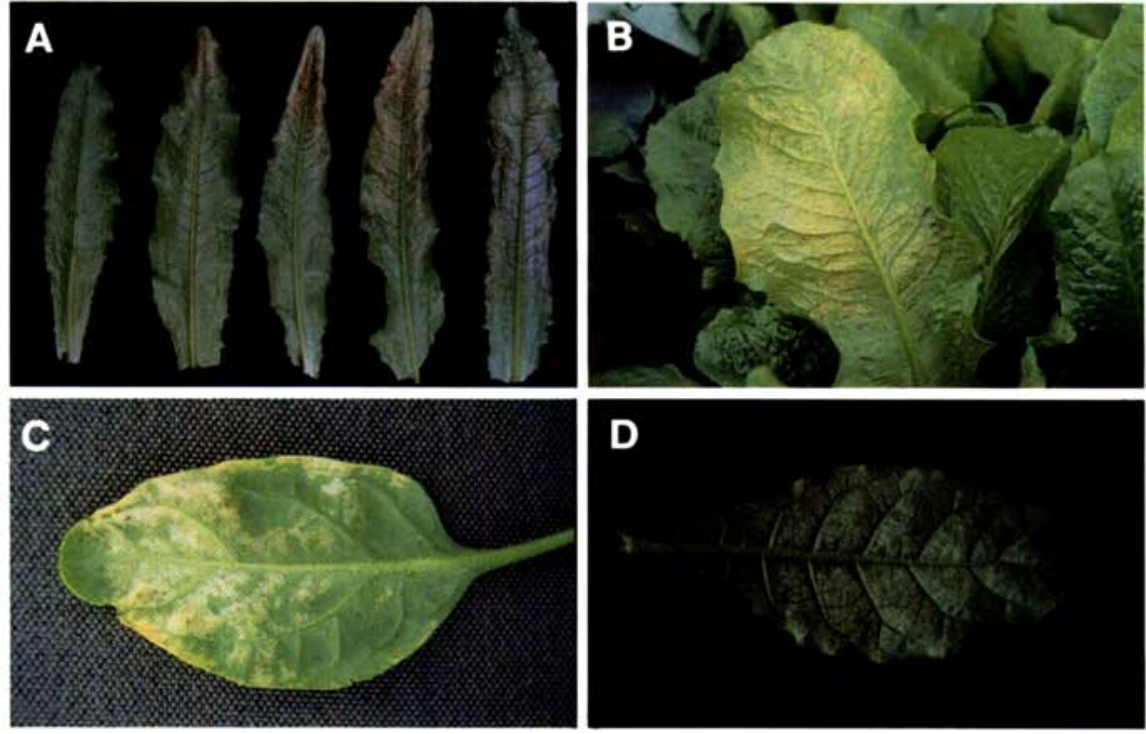

Fig. 5. Symptoms induced by peroxyacetyl nitrate on abaxial surface of leaves: (A) Bronzing and necrosis of lettuce from Taipei area where ambient concentration of peroxyacetyl nitrate exceeded $22 \mathrm{ppb}$, (B) bronzing and silvering of lettuce from a field close to an urban area, (C) silvering of spinach, and (D) silvering of tobacco from Taipei area.

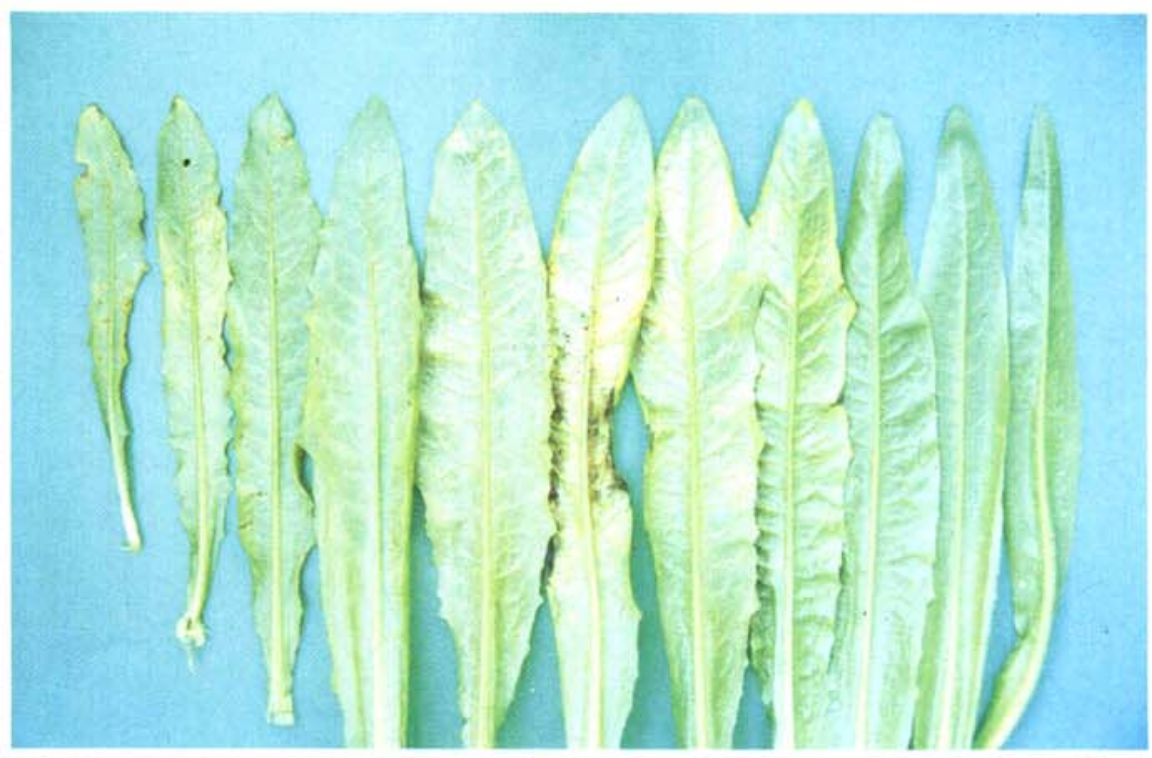

Fig. 6. Lettuce leaves collected from suburban area in Kaohsiung County during April 1990 and arranged from oldest (right) to youngest (left). Symptoms on the fourth through seventh leaves and ninth through eleventh leaves from the right indicate at least two periods of elevated concentrations of peroxyacetyl nitrate during the month.

(6), they cause quite different symptoms (7). Sword-leaf and Round-leaf lettuce are very sensitive to PAN but tolerant to ozone. For this reason, these two cultivars have been used extensively as selective bioindicators in the study of spatial and temporal distribution of PAN in Taiwan $(6,14)$. They are planted yearround and grow rapidly, producing a new alternate leaf approximately every 3 days. Fully developed leaves show a transverse band of bronzing and silvering symptoms about 1-2 days after exposure to PAN, whereas fully mature and very young leaves do not show symptoms. Therefore, progressive development of leaves can furnish a historical record of phytotoxic levels of PAN exposures in a certain area. For example, 11 leaves of Sword-leaf lettuce collected from Kaohsiung County in April 1990 were arranged with the youngest on the right and the oldest on the left (Fig. 6). Symptoms on the fourth through seventh leaves and the ninth through eleventh leaves indicated exposures to elevated concentrations of PAN on days 12 through 15 and days 27 through 30 , respectively. This approach was used to determine that PAN concentrations were elevated one or two times per month throughout the year in Taipei County 
and two to five times per month during the winter in Kaohsiung County (14).

Indicator plants have been used extensively in Taiwan to diagnose foliar injury induced by air pollutants and to monitor air pollution $(5,9,12)$. Advantages include low cost compared with expensive air-quality monitoring instruments, an almost unlimited number of plants that can be grown over very wide geographic areas, and ease of evaluation. Indicator plants are particularly useful for plant pathologists and environmentalists, since a given area or industrial park in Taiwan frequently encompasses many types of industries. The nature of a point-source plume dispersion allows specific foliar injury symptoms to be related to the emission source in the vicinity $(12,13)$.

\section{Perspective for the Future}

In Taiwan, injury to vegetation induced by air pollution is controlled mainly through reduction of emissions and consequently air concentrations of phytotoxic pollutants. The government has developed procedures to control pollution from industries, but the emissions from motor vehicles, especially from motorcycles, are still a major problem. This may be the main reason for the appearance of PAN-type symptoms on sensitive plant species in all major urban areas in recent years (14). Enforcement of emission limits and construction of mass-transit systems from suburban to metropolitan areas to reduce the number of vehicles are two major approaches to solving the smog problem. A mass-transit system is currently being constructed at Taipei and one is in the planning stage at Kaohsiung. PAN-induced foliar injury to crops is expected to decrease in the future in these two densely populated counties.

The public in Taiwan has been very involved in reducing the amount of primary air pollutants over the last decade. Previously, cryolite had been used in some ceramic factories as an ingredient in the manufacture of porcelain. Because cryolite has a high fluoride content, emissions from these factories contained very high concentrations of hydrogen fluoride and caused severe damage to crops and trees in the vicinity. Protests from residents and farmers, coupled with the enforcement of emission limits set by the Taiwan EPA, led the industries to abandon the use of cryolite.

A lawsuit brought by some banana growers in southern Taiwan forced the closing of several brick factories. When new factories were constructed, to save energy and reduce labor costs the kiln design was changed from the conventional dome-shaped downdraft type to a modern tunnel type that utilizes residual heat for drying and preheating clay blocks. When hydrogen fluoride released from the clay blocks in the brick-forming chamber $(>1,000 \mathrm{C})$ passed through the tunnel, about $98 \%$ was reabsorbed by the clay blocks drying in the tunnel. The kiln modifications therefore unintentionally solved the banana marginal scorch problem.

With increasing experience and growing public awareness, air quality in Taiwan is expected to improve. We should continue to determine the sensitivities and responses of various plant species to different air pollutants so that extension agents can advise growers whose crops are subjected to such pollution.

\section{Acknowledgments}

I thank W. H. Ko of the Department of Plant Pathology, University of Hawaii, for his critical review of the manuscript. This study was supported in part by grant NSC79-0421-B-002-19Z from the National Science Council of the Republic of China.

\section{Literature Cited}

1. Anonymous. 1992. Republic of China Yearbook 1991-92. Kwang Hwa Publishing Co., Taiwan.

2. Brewer, R. F. 1966. Flourine. Pages $180-$ 196 in: Diagnostic Criteria for Plant and Soil. H. D. Chapman, ed. Quality Printing Co., Abilene, TX.

3. Environmental Protection Administration. 1987. The 1986 Environmental Protection Yearbook of Taiwan, Republic of China.

4. Environmental Protection Administration. 1991. The 1991 Environmental Databook of Taiwan, Republic of China.

5. Heggestad, H. E. 1991. Origin of Bel-W3, Bel-C and Bel-B tobacco varieties and their use as indicators of ozone. Environ. Pollut. 74:264-292.

6. Huang, M. H. 1993. Studies on the effects of peroxyacetyl nitrate on plants in Taipei area. M.S. thesis. National Taiwan University, Taipei.

7. Jacobson, J. S., and Hill, A. C., eds. 1970. Recognition of Air Pollution Injury to Vegetation: A Pictorial Atlas. Air Pollution Control Association, Pittsburgh, PA.

8. Ott, W. R., and Hunt, W. F., Jr. 1976. A quantitative evaluation of the pollutant standards index. J. Air Pollut. Control Assoc. 26:1050-1054.

9. Steubing, L., and Jager, H. J. 1982. Monitoring of Air Pollution by Plants: Methods and Problems. Dr. W. Junk Publishers, The Hague.

10. Street, O. E., Sung, C. H., Wu, H. Y., and Menser, H. A., Jr. 1971. Studies on weather fleck of tobacco in Taiwan. Tob. Sci. 15:128-131.

11. Su, H. J., Ko, W. H., Chuang, T. Y., Huang, M. T., and Hwang, S. C. 1978. Etiological studies on marginal scorch of banana, with special reference to airpolluted fluoride associated with the disease. Taiwan Banana Res. Inst. Spec. Issue 21:1-21

12. Sun, E. J. 1985. Identification of Air Pollution Injury to Vegetation and the Atlas. Bureau of Environmental Protection, Taiwan, ROC.

13. Sun, E. J. 1989. Discoloration of rice leaves caused by ammonia gas released from refrigeration factory. Plant Prot. Bull. 31:256-262.
14. Sun, E. J. 1993. Effects of peroxyacetyl nitrate on lettuce plants in Taiwan. Pages 183-200 in: Proc. Workshop Effects Air Pollut. Agrometeorol. Crop Prod. Taiwan.

15. Sun, E. J. 1993. Ozone injury to leafy sweet potato and spinach in northern Taiwan. Pages 111-126 in: Proc. Workshop Relat. Atmos. Qual. Agric. Manage.

16. Sun, E. J., and Su, H. J. 1985. Fluoride injury to rice plants caused by air pollution emitted from ceramic and brick factories. Environ. Pollut. Ser. A. 37:335342.

17. Sung, C. H., Chen, H. H., and Wu, J. K. 1973. Air pollution related to tobacco weather fleck. Pages 38-41 in: 1973 Annual Report of Taiwan Tobacco Research Institute. Taiwan Tobacco and Wine Monopoly Bureau, Taichung.

18. Taylor, O. C., and MacLean, D. C. 1970. Nitrogen oxides and the peroxyacyl nitrates. Pages E1-E14 in: Recognition of Air Pollution Injury to Vegetation: A Pictorial Atlas. J. S. Jacobson and A. C. Hill, eds. Air Pollution Control Association, Pittsburgh, PA.

19. Temple, P. J., and Taylor, O. C. 1983. World-wide ambient measurements of peroxyacetyl nitrate (PAN) and implications for plant injury. Atmos. Environ. 17:1583-1587.

20. Treshow, M., and Pack, M. R. 1970. Fluoride. Pages D1-D17 in: Recognition of Air Pollution Injury to Vegetation: A Pictorial Atlas. J. S. Jacobson and A. C. Hill, eds. Air Pollution Control Association, Pittsburgh, PA.

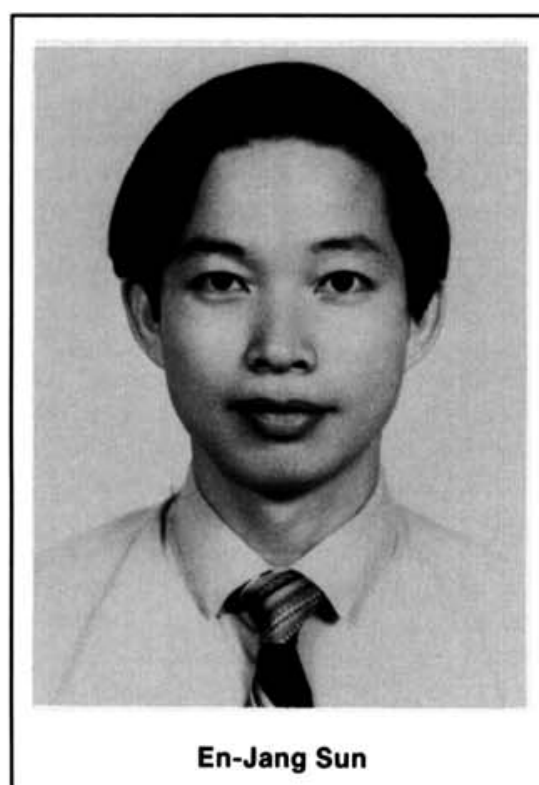

Dr. Sun is an associate professor of plant pathology at National Taiwan University, Taipei. He received his B.S., M.S., and Ph.D. degrees from National Taiwan University. His research interests cover all aspects of plant injury caused by industrial pollution, with special emphasis on air pollution. Before joining the university, he was a senior specialist in charge of plant diseases associated with industrial pollution at the Taiwan Environmental Protection Administration. 